\title{
Effects of Internal Control Systems on Financial Performance of Sugarcane outgrowercompanies inKenya
}

\author{
Mwakimasinde Mary ${ }^{1}$ Odhiambo Albert ${ }^{2}$ Prof John Byaruhanga ${ }^{3}$ \\ 1 (School of business and economics MasindeMuliro University of Science and TechnologyKenya) \\ 2. (Lecturer of Accounting and Finance school of business and economics MasindeMuliro University of Science \\ and Technology Kenya) \\ 3. (Lecturer of economicsschool of business and economics MasindeMuliro University of Science and \\ Technology Kenya)
}

\begin{abstract}
This study was designed to investigate the effect of internal control systems on the financial performance of sugarcane outgrower companies in Kenya.The study adopted a descriptive correlational survey design. All the sugarcane outgrower companies were studied. Both the primary and secondary data was collected. Primary data was collected from the key informants from all the nine outgrower companies in Kenya using questionnaires. Secondary data was extracted from annual reports, publications and document analysis. The key informant's method was used, hence, all the Finance Managers and heads of internal audit for every outgrower company were selected to take part in the study. The data collection instruments were administered to all the nine sugarcane outgrower institutions. The data was analysed using statistical package for social scientists (SPSS) computer software version 19.0 to generate cumulative frequencies and percentages. The study found a positive significant effect of internal control system on the financial performance $(R=0.682)$, and $R$ square 0.428 thus internal control components accounts for $42,8 \%$ variance in performance The findings are expected to be of value to the sugarcane outgrower stakeholders and form a basis for improving financial performance of sugarcane outgrower companies.
\end{abstract}

Key Words: Internal Control, Control environment, Control activity, Financial performance

\section{Background To The Study}

The French Institute of Chartered Accountants defines internal control systems as a set of security measures which contribute to the control of a company. Its aim is to ensure the security and safeguard of assets and the quality of information. It plays an important role in preventing and detecting fraud and protecting the organization's resources, both physical (machinery and property) and intangible (reputation or intellectual property such as trademarks).

At the organizational level, internal control objectives relate to the reliability of financial reporting, timely feedback on the achievement of operational or strategic goals, and compliance with laws and regulations (Kenya Company's Act cap 486). At the specific transaction level, internal control refers to the actions taken to achieve a specific objective (like how to ensure the organization's payments to third parties are for valid services rendered.) Internal control procedures reduce process variation, leading to more predictable outcomes (Saleemi 1997).

In the Kenya sugar industry, sugarcane farmers are organized in cooperatives and outgrower companies. The sugar cooperatives exist among the sugar-cane farmers in Mumias, Chemelil, Nzoia, Butali, Soin, West Kenya and Muhoroni. These outgrower organizations ought to be understood within the broadest framework of cooperative movements in Kenya with the enactment of Cooperative Societies Act of 1966. Underlying the enactment of this legislation was the perception by the Kenyan policymakers that cooperatives could provide viable instruments for integrating smallholders with the modern economy. In this role, cooperatives would offer a service network in rural areas, which combined first stage processing and marketing with supply of credit and inputs. Other objectives of these organizations include acting as the mouth piece for their members in relation to the Government, the Millers and all other sugarcane stake holders. They are also empowered to protect the farmers' interest in relation to sugarcane pricing and acquiring affordable farm inputs, and are charged with improving their members' welfare by providing them with non-core business such as dairy farming, bee keeping and other food projects (KSA 1999).

In an effort to make the views of the ordinary farmers felt an umbrella organization for all the individual farmers' organizations was established in 1982. The organization known as the Kenya Sugar Growers' Association (KESGA). One problem the farmers face even with KESGA in place is the lack of experience in dealing with issues affecting their members as compared to farmers in the tea or even coffee industry. The latter farmers have had organizations for more years than the sugarcane farmers. Challenges facing outgrower companies in Kenya, just to name a few are that almost all outgrower organizations have not 
performed to the expectations of farmers. There are many reasons for this state of affairs. First is the deliberate misuse of funds by the officials of the organizations. Thus to fully understand and appreciate the pattern and behavior of these outgrower organizations, it is imperative to shift the focus within a wider set of institutionalized power, while taking into consideration factors such as social capital attendant therein (KSB 2003).

\section{Statement of the problem}

There is a general consensus that internal Control systems are used as management tools in financial management (Shah 2003). In view of the foregoing virtually all the sugarcane Outgrower Organizations have established Internal Control measures in order to enhance their financial reporting systems, check on their efficiency and effectiveness of operations as well as enhance adherence to the prescribed rules and regulations. However the latest (Kenya Sugar Board Report 2012) shows that management of sugarcane outgrower companies are performing below expectations and this is exemplified in the poor returns they post for their clients-the farmers. It is also revealed that members are unhappy with outgrower services and keep staging protests. Several Outgrower organizations have gone under and others are barely providing farmers with services they have to.

\section{Objective of the study}

The specific objective of the study was;To determine the effect of internal control system components on the financial performance of the Sugarcane Outgrower Companies.

\section{Research Hypothesis}

The study was guided by the following hypothesis; $\mathrm{H}_{01}$ Components of internal control systems have no significant effect on the financial performance of Sugarcane Outgrower organizations.

\section{Scope of the study}

The scope of this study was limited to the sugarcane Outgrower companies in Kenya. The study involved the nine sugarcane outgrower companies namely Mumias, Nzoia, West Kenya, Sony, Butali, Soin, Chemilil and Muhoroni.

Independent Variables

\section{INTERNAL CONTROL SYSTEM}

- Control environment

- Risk assessment process

- Information system

- Control activities

\section{Conceptual Framework}

\section{Dependent variables}

FINANCIAL PERFORMANCE

- Cost per unit

- Goal attainment

- Profitability/Surplus

\section{Empirical review}

\section{Literature Review}

Muraleetharan(2010) in his study of internal control and its impact on financial performance of organisation university of Jaffnan, chi square test was used and the value of $161.1(\mathrm{p}=0)$ at 0.05 significant level indicated that there was a relationship between internal control and financial performance $\mathrm{R}^{2}=0,818$ which revealed that it explains $81.8 \%$ of variance in performance in performance.

Chukwu P. (2012) in the study the impact of internal control system on the financial Management of an organization (a case study of the Nigeria bottling company plc, enugu) internal control measure does ensure proper use of organisation fund and assets. The $\mathrm{Z}$ value at 3 degree of freedom and 5\% significant for two tailed test was 0.9989 which is less than table value 2.6. The study also found that fraud perpetrationand losses of revenue in an organisation are not a result of internal control system

\section{Component of Internal Control System}

The internal control systems consist of components used were control environment; the entities risk assessment process, the information system, control activities and the monitoring of controls (ISA UK and Ireland 315). 


\section{Control Environment}

The control environment includes the attitudes, awareness, and actions ofmanagement and those charged with governance concerning the entity's internal control and its importance in the entity. Hooks (1994) describes the Control Environment as in part an operationalization of organization culture. The control environment encompasses the following elements (ISA UK and Ireland 315): Communication and enforcement of integrity and ethical values is an element of control environment; the effectiveness of controls cannot rise above the integrity and ethical values of the people who create, administer, and monitor them. Integrity and ethical values are essential elements of the control environment which influence the effectiveness of the design, administration, and monitoring of other components of internal control. They include management's actions to remove or reduce incentives and temptations that might prompt personnel to engage in dishonest, illegal, or unethical acts. Armstrong (1999) says that managers can contribute to enhancing the awareness of ethical issues by:

\section{Deploying Professionals}

Deploying professionals to develop and communicate an ethic policy and field the response to it, holding training sessions to help people think through the issues and monitory policy. Second is by contributing to the formation of company strategy especially through touching on mission and values. Lastly by setting an example through professional conduct, on issues such as fairness, equal treatment and confidentiality. Policy statements and codes of conduct can also be used to communicate the entity's values and behavioral standards to personnel and by example.(ISA UK and Ireland 315)

\section{Commitment to Competence}

Commitment to competence (ISA UK and Ireland 315) is the second element of the control environment. Competence is the knowledge and skills necessary to accomplish tasks that define the individual's job. Commitment to competence includes management's consideration of the competence levels for particular jobs and how those levels translate into requisite skills and knowledge. Armstrong (1999) assesses that the concept of competency has achieved this degree of prominence because it is essentially about performance. It is directly concerned with the factors contributing to high levels of individual contribution and therefore, organizational effectiveness. He adds that an obsession with competency building will characterize the global winners.

\section{Participation by those charged with Governance}

An entity's control consciousness is influenced significantly by those charged with governance. Attributes of those charged with governance include independence from extent of their involvement and scrutiny of activities, the management, their experience and stature, the appropriateness of their actions, the information they receive, the degree to which difficult questions are raised and pursued with management, and their interaction with internal and external auditors. The importance of responsibilities of those charged with governance is recognized in codes of practice and other regulations or guidance produced for the benefit of those charged with governance. Other responsibilities of those charged with governance include oversight of the design and effective operation of whistle blower procedures and the process for reviewing the effectiveness of the entity's internal control (ISA UK and Ireland 315).

\section{Management's Philosophy and Operating Style}

Management's philosophy and operating style encompass a broad range of characteristics. Such characteristics may include: Management's approach to taking and monitoring business risks; management's attitudes and actions toward financial reporting (conservative or aggressive selection from available alternative accounting principles, and conscientiousness and conservatism with which accounting estimates are developed); and management's attitudes toward information processing and accounting functions and personnel.(ISA UK and Ireland 315)

\section{Organizational Structure}

An entity's organizational structure provides the framework within which its activities for achieving entity-wide objectives are planned, executed, controlled, and reviewed. Establishing a relevant organizational structure includes; considering key areas of authority, responsibility and appropriate lines of reporting. An entity develops an organizational structure suited to its needs. The appropriateness of an entity's organizational structure depends, in part, on its size and the nature of its activities. Armstrong (1999) regards a structure of an organization as a framework for getting things done. It consists of units, function, divisions departments, and formerly constituted: work teams into which activities related to particular process projects, products, market, customers, geographical areas or professional disciplines are grouped together. The structure indicates who is accountable for directing and carrying out these activities and defines management hierarchies. It spells out 
broadly who is responsible for whom for what at each level in the organization.

\section{Assignment of Authority and Responsibility}

This factor includes how authority and responsibility for operating activities are assigned and how reporting relationships and authorization hierarchies are established. It also includes policies relating to appropriate business practices, knowledge and experience of key personnel, and resources provided for carrying out duties. In addition, it includes policies and communications directed at ensuring that all personnel understand the entity's objectives, know how their individual actions interrelate and contribute to those objectives, and recognize how and for what they will be held accountable.

\section{Human Resource Policies and Practices}

Pearce II (2011) highlights tactics of human resource as; Recruitment selection and orientation, carrier development and training, compensation, evaluation discipline and control and labour relations and equal opportunity requirements. Human resource policies and practices relate to recruitment, orientation, training, evaluating, counseling, promoting, compensating, and remedial actions. For example, standards for recruiting the most qualified individuals - with emphasis on educational background, prior work experience, past accomplishments, and evidence of integrity and ethical behavior demonstrate an entity's commitment to competent and trustworthy people. Training policies that communicate prospective roles and responsibilities and include practices such as training schools and seminars illustrate expected levels of performance and behavior. Promotions driven by periodic performance appraisals demonstrate the entity's commitment to the advancement of qualified personnel to higher levels of responsibility.

Small entities may implement the control environment elements differently than larger entities. For example, small entities might not have a written code of conduct but, instead, develop a culture that emphasizes the importance of integrity and ethical behavior through oral communication and by management example. Similarly, those charged with governance small entities may not include an independent or outside member (ISA UK and Ireland 315, COSO: 2005).

\section{Entity's Risk Assessment Process}

An entity's risk assessment process is its process for identifying and responding to business risks and the results thereof. For financial reporting purposes, the entity's risk assessment process includes how management identifies risks relevant to the preparation of financial statements that give a true and fair view (or are presented fairly, in all material respects) in accordance with the entity's applicable financial reporting framework, estimates their significance, assesses the likelihood of their occurrence, and decides upon actions to manage them. For example, the entity's risk assessment process may address how the entity considers the possibility of unrecorded transactions or identifies and analyzes significant estimates recorded in the financial statements (KASNEB 2011). Risks relevant to reliable financial reporting also relate to specific events or transactions. Shah (2011) asserts that one would incur more risk if he decides to invest in shares rather than Government bonds. However he asserts that risk and expected return move in tandem; the greater the risk the greater the expected return.

Chandra (2002) note that Risk is everywhere and surrounds our personal activities or professional lives. Though it is difficult to eliminate completely, one can minimize risk by employing risk assessment techniques in his personal and professional capacity. Richie (1989) indicates that data protection is a must, appropriate security measure, shall be taken against unauthorized access or alteration, disclosure or destruction of personal data against accidental loss or destruction.. Management may be aware of risks related to these objectives without the use of a formal process but through direct personal involvement with employees and outside parties (ISA UK and Ireland 315, COSO: 2005)..

\section{Information System}

It includes the related business processes, relevant to financial reporting and communication. An information system consists of infrastructure (physical and hardware components), software, people, procedures, and data. Infrastructure and software have less significance, in systems that are exclusively or primarily manual. Many information systems make extensive use of information technology (IT). IT as defined by Williams et al (1999) is technology that merges computing with high speed communications links carrying data, sound and video.

Accordingly, an information system encompasses methods and records that: Identify and record all valid transactions. Describe on a timely basis the transactions in sufficient detail topermit proper classification of transactions for financial reporting. Measure the value of transactions in a manner that permits recording their proper monetary value in the financial statements. Determine the time period in which transactions occurred to permit recording of transactions in the proper accounting period. Present properly the transactions and related disclosures in the financial statements. Williams et al (1999) stresses that protection of information system 
entails; control of access, audit controls that track that track servers and programs, and people controls (check resumes to confirm training and separate employee functions, input controls, and output controls).

\section{Control Activities}

Control activities are the policies and procedures that help ensure that management directives are carried out, for example, that necessary actions are taken to address risks that threaten the achievement of the entity's objectives. Control activities, whether within IT or manual system, have various objectives and are applied at various organizational and functional levels. Generally, control activities that are relevant to an audit may be categorized as policies and procedures that pertain to the following:Performance reviews; These control activities include reviews and analyses of actual performance versus budgets, forecasts, and prior period performance; relating different sets of data, operating or financial to one another, together with analyses of the relationships and investigative and corrective actions; comparing internal data with extern al sources of information; and review of functional or activity performance, such as a bank's consumer loan manager's review of reports by branch, region, and loan type for loan approvals and collections(ISA 315).

\section{Information Processing}

A variety of controls are performed to check accuracy, completeness, and authorization of transactions. The two broad groupings of information systems control activities are application controls and general ITcontrols. Application controls apply to the processing of individual applications. These controls help ensure that transactions occurred, are authorized, and are completely and accurately recorded and processed. Examples of application controls include checking the arithmetical accuracy of records, maintaining accounts, reviewing accounts and trial checks, and manual follow-up of exception reports. This control helps enhance organizational performance since wastages that accrue from inaccuracy are prevented or discovered if any. General IT- balances, automated controls such as edit checks of input data and numerical sequence controls are policies and procedures that relate to many applications and support the effective functioning of application controls by helping to ensure the continued proper operation of information systems. General IT-controls commonly include controls over data center and network operations; system software acquisition, change and maintenance; access security; and application system acquisition, development, and maintenance. These controls apply to mainframe, mini frame, and end-user environments. Examples of such general IT- controls are program change controls, controls that restrict access to programs or data, controls over the implementation of new releases of packaged software applications, and controls over system software that restrict access to or monitor the use of system utilities that could change financial data or records without leaving an audit trail. The general IT controls enhance the security of both software and hardware thus safeguarding information and thus preventing the losses that accompany loss of information; it also guarantees the safety of confidential records. Therefore competitors and rivals cannot access this information. William et al (1999) elaborates threats to computers and communication systems as; Errors and accidents, natural and other hazards, crime against computers and communication, worms and viruses and computer criminals.

\section{PhysicalMonitoring Controls}

These activities encompass the physical security of assets, including adequate safeguards such as secured facilities over access to assets and records; authorization for access to computer programs and data files; and periodic counting and comparison with amounts shown on control records. Losses may occur if for example there is no comparing of the results of cash, security and inventory counts with accounting records. Frauds are discovered in these controls and hence improving the organizational performance. The extent to which physical controls intended to prevent theft of assets are relevant to the reliability of financial statement preparation, and therefore the audit, depends on circumstances such as when assets are highly susceptible to misappropriation. For example, these controls would ordinarily not be relevant when any inventory losses would be detected pursuant to periodic physical inspection and recorded in the financial statements. However, if for financial reporting purposes management relies solely on perpetual inventory records, the physical security controls would be relevant to the audit. Stealing of assets as commented on by Williams et al (1999) can range from shoplifting an accessory, diskettes and software from a store to taking a whole large asset. This when prevented enhances organizational performance.

\section{Segregation Of Duties}

Asoke (2005) underscored the importance of segregation of duties that the likelihood of fraud and the theft, which may reduce organizational performance, is reduced if it becomes necessary to collude with others to accomplish an offence. For example, a person selling seats to a movie may be tempted to pocket some money received from customers who enter the theatre. This temptation is realized if the person staffing the box office is required to issue tickets that are then collected by a different employee as people come into the theatre. Manasseh 
(2004) also noted that segregation of duties reduces the risk of fraud and error and manipulation in the business thus increasing efficiency in the company's operations and improving performance. Plan of organization should describe proper separation of functional responsibilities. Authorizing transactions and running a department should not be the responsibility of one person. Assigning different people the responsibilities of authorizing transactions, recording transactions, and maintaining custody of assets is intended to reduce the opportunities to allow any person to be in a position to both perpetrate and conceal errors or fraud in the normal course of the person's duties. Examples of segregation of duties include reporting, reviewing and approving reconciliations, and approval and control of documents. Certain control activities may depend on the existence of appropriate higher level policies established by management or those charged with governance. For example, authorization controls may be delegated under established guidelines, such as investment criteria set by those charged with governance; alternatively, non-routine transactions such as major acquisitions or divestments may require specific high level approval, including in some cases that of shareholders. This will help curb malpractices like a rogue employee selling a company asset without proper authority. The concepts underlying control activities in small entities are likely to be similar to those in larger entities, but the formality with which they operate varies. Further, small entities may find that certain types of control activities are not relevant because of controls applied by management. For example, management's retention of authority for approving credit sales, significant purchases, and draw-downs on lines of credit can provide strong control over those activities, lessening or removing the need for more detailed control activities. An appropriate segregation of duties often appears to present difficulties in small entities. Companies that have only a few employees, however, may be able to assign their responsibilities to achieve appropriate segregation or, if that is not possible, use management oversight of the incompatible activities to achieve control objectives (ISA UK and Ireland 315).

\section{Financial Performance}

Financial performance of sugarcane outgrower Institutions can be gauged via the degree of attainment of their organizational objectives like meeting both short-term and long-term objectives as and whenever they fall due. The scarce resources of the organization are not supposed to be pumped into white elephants. Optimal resource utilization should ensure maximum output in the projects named in the organizational objectives. Organizations cannot afford to waste their limited financial and skilled man power resources on unproductive ventures. Investment projects must be chosen not only on the basis of partial productivity of overall development program which takes account of external economics indirect repercussion and long term objectives. Skilled manpower must be utilized where its contribution will be widely felt. Economic planning is assumed to help modify the restraining influence of limited resources by recognizing the existence of a particular constraint and by choosing and coordinating investment projects so as to channel the scarce resources into their most productive outlets (Gupta 1999). However, financial performance in this study was gauged by profitability/surplus, cost per unit and degree of goal attainment.

\section{Profit/Surplus}

This is a control dimension that ensures that users of financial information, who include all the stake holders, get an accurate and reliable summary which communicates the firm's financial affairs (Pandey 2002). Ajowi (2005) notes that the financial reports should secure as far as possible the accuracy and completeness of the company's records, to detect and prevent errors and frauds and to ensure the safety and adequacy of the accounting system for availability of true and fair view financial statements In the long term there is still a question mark in terms of sustainability of benefits of Outgrowers institutions due to their over dependency on support services, extension services, seeds provision, credits and centralized market for sugarcane. It is worth to mention that the sugar industry is promoting and supporting the creation of Outgrower associations to enhance income from members. The sugar industry in Kenya is confronted with various stiff challenges including competition from all Common Markets for East and Southern Africa (COMESA) products. Cheap imports from member countries affect sales revenues from local industries, a negative effect which trickles down to performance of outgrower companies, since they largely depend on local mother companies for sustenance.

Organizations in the sugar industry are supposed to strive for excess of assets over liabilities. Outgrower organizations have over the years shown poor financial performance. Excellent financial performance will thus be seen in the number of demonstration projects running, acreage of sugarcane, annual number of tones delivered to the miller, loans advanced to members and returns on capital employed. Optimal resource utilization also is a boost to the company's sustainability. Thus the companies are supposed to have excess of assets over liabilities so as to remain viable. Income from members, income from projects and other funding are not enough sources of funds for sugarcane Outgrower organizations thus the need for proper internal control procedures. The companies in their bid to sort for funds for development should not engage in too much borrowing that can course financial distress to the companies. Perusal in MOCO books shows that in the year 2004, the bank overdraft was Sh. 33,999,033 and 1,474,889 in 2005. Sh. 875,399,673 was owing as current 
liabilities in 2004 and Sh. 555,444,625 in 2005. This is an indication that there is engagement in excessive uncontrolled activities. (MOCO Financial Report 2004).3

\section{Goal attainment}

Among all companies' stake-holders goals, shareholders major goal is to maximize their wealth (Pandey 2002). Efficiency is optimal usage of organizational resources and minimization of wastage. Ajowi (2005) lists the principal objectives of Internal Control system as; to enable management of the entity to carry on the business in an orderly and efficient manner, to ensure adherence to the management policies and procedures, to ensure for the safeguarding of the Company's assets against misuse theft and misappropriation. Millichamp (2002) stresses that the objectives of the internal control system run through all areas of activity usually found in a business. These include areas like cash and Cheques received by post, cash and sales collection, payment into a bank, cash and bank balances, stock and work in progress, wages and salaries, purchases and creditors and sales and debtors.

\section{Cost per unit}

A firm that seeks to build a competitive advantage has to use one of the three generic strategies namely; low cost production, unique product or premium pricing and low cost advantage (Porter et al 1993). Companies should strive for low cost in the industry and gain the advantage of high profits. This enables a company to be able to defend its price wars and have an edge against its competitors to gain a larger market share and maximize revenue (Pearce 2010). A company may also gain a competitive edge by creating a market unique product for various customer groups through differentiation (Porter et al 1993). Products are designed to appeal to customers with special sensitivity for a particular product attribute to build customer loyalty, which translates into a company's ability to charge premium prices. The study proposes that low cost strategy if adopted may be useful and may positively affect the company's financial performance. In Kenya companies acquire farm inputs at very exorbitant prices making the end product very expensive as compared to similar products from the other Comesa countries.

\section{Research Design}

This study used descriptive correlational survey design as it sought to describe and establish the relationships among the study variables. A research design is the arrangement of conditions for collection, measurement and analysis of data in that aims to combine relevance to the research purpose Kothari (2010). Correlational survey design also allows a researcher to measure the research variables by asking questions to the respondents and then examining their relationship (O’Connon, 2011).

\section{Study AreaAnd Population Of The Study}

The study was carried out in Kenya. Sugarcane outgrower companies in Kenya are mainly found in Bungoma, Kakamega, Kisumu, Kericho and Migori Counties. Sugarcane farming supports directly or indirectly over five million people in Kenya (KSB, 2012). Kenya is located in East Africa. It lays approximately $5^{\circ} \mathrm{N}, 4.5^{0}$ $\mathrm{S}$ and $34^{\circ} \mathrm{E}$ and $42^{\circ} \mathrm{W}$. The country shares its boundary with Ethiopia in the north, Tanzania in the south, Somalia in the northeast and Uganda in the west. Great Rift Valley divides the highlands of Kenya. This being a census study, all the sugarcane Outgrower companies in Kenya which are annexed to sugar millers registered and licensed by the ministry of co-operative and industrialization as at May 2012, and were still in operation at the time of data collection were be studied. The elements of the study population were eighteen, thus two target persons from each company.

\section{Data Collection Instruments}

Both primary and secondary data were used in this study.Primary data was collected through the use of key informant method and a self- administered questionnaire. Hence, all the Finance Managers and Heads of Internal Audit were selected to take part in the study as they are perceived to be knowledgeable on the issues under study and for which they are either responsible for their execution or they personally execute them. Only two respondents were interviewed in each outgrower company and the questionnaire had both the open and closed ended questions and 'drop and pick' technique was used. Secondary data on the other hand, was obtained from the already written literature on the outgrower companies which was be used to cross-validate and check the consistency of the questionnaire responses

\section{Reliability of Research Instruments}

Reliability refers to the measure of the degree to which a research instrument yields consistent results on across time and across the various items of the instrument (Sekaran, 2003). It is the extent to which an 
instrument is predictable, stable, accurate and dependable to yield the same results every time it is administered. The measures of independent variable had Cronbach's alpha coefficient of 0.7620 (Table 3.2) while those of the dependent variable had Cronbach's alpha coefficient of 0.7801 (Table 3.3). The study measures were found to be highly reliable in that they all had alpha coefficient greater than the minimum accepted Cronbach's alpha coefficient of 0.70 (Santos, 1999).

Table 3.2: Reliability Statistics for Internal Control System

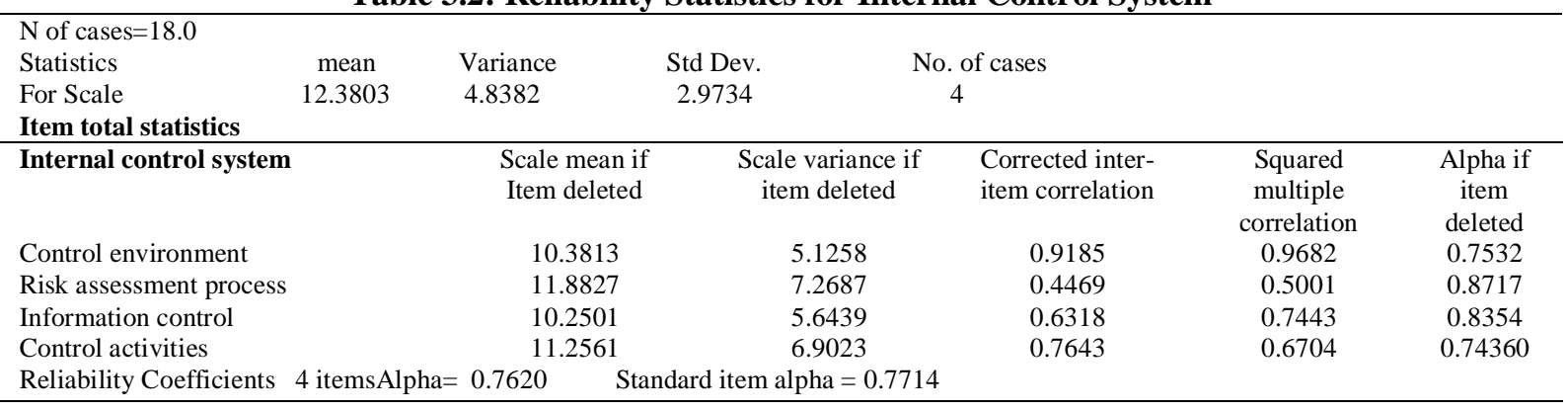

Table 3.3 Reliability Statistics for Performance of Sugarcane outgrower companies

\begin{tabular}{|c|c|c|c|c|c|c|}
\hline $\begin{array}{l}\mathrm{N} \text { of cases }=18.0 \\
\text { Statistics } \\
\text { for Scale } \\
\text { Item total statistics }\end{array}$ & $\begin{array}{c}\text { mean } \\
14.7521\end{array}$ & $\begin{array}{l}\text { Variance } \\
3.6434\end{array}$ & $\begin{array}{r}\text { Std Dev. } \\
1.1057\end{array}$ & \multicolumn{2}{|c|}{$\begin{array}{c}\text { No. of cases } \\
3\end{array}$} & \\
\hline Performance & $\begin{array}{l}\text { Sca } \\
\text { Iter }\end{array}$ & $\begin{array}{l}\text { lean if } \\
\text { leted }\end{array}$ & $\begin{array}{l}\text { Scale variance if } \\
\text { item deleted }\end{array}$ & $\begin{array}{l}\text { Corrected inter- } \\
\text { item correlation }\end{array}$ & $\begin{array}{l}\text { Squared } \\
\text { multiple } \\
\text { correlation }\end{array}$ & $\begin{array}{c}\text { Alpha if item } \\
\text { deleted }\end{array}$ \\
\hline Cost per unit & & 540 & 4.6431 & 0.9551 & 0.5023 & 0.7767 \\
\hline Goal attainment & & 001 & 5.5712 & 0.7094 & 0.6150 & 0.8416 \\
\hline Profitability or surplus & & 020 & 4.6430 & 0.9553 & 0.5150 & 0.7745 \\
\hline Reliability Coefficients & 3 itemsAl & $=0.7801$ & Standard item a & $=0.7890$ & & \\
\hline
\end{tabular}

\section{Data Analysis And Presentation}

The data collection instruments were administered to all the nine sugarcane Outgrower companies. After the data had been collected, the researcher edited them to ensure their completeness and consistency, Coding and classification then followed to ensure sufficient analysis. The data was analyzed by simple descriptive analysis using statistical package for social scientists (SPSS) computer software.

Both descriptive and inferential statistics were used in the analysis then presented using frequency and contingency tables. Descriptive statistics was used to deduce any patterns, averages and dispersions in the variables. They include measure of locations (mean) and measure of dispersions (standard error mean). Inferential statistics was used to determine the relationship between the study variables and these inferential statistics includes correlation and regression analyses.

The researcher used Karl Pearson's first order partial coefficient $\left(\mathrm{r}_{\mathrm{xy} . \mathrm{z}}\right)$. The relationship between internal control system and financial performance was expected to follow a regression model of the nature

$\mathrm{P}=\alpha+\beta_{1}$ ics $+\varepsilon$ where;

$\mathrm{P}=$ Financial Performance of sugarcane Outgrower companies indicators

$\alpha=$ intercept term

$\beta_{1}=$ Beta coefficient

ICS= Internal Control System

$\varepsilon=$ Error term

\section{Ethical Consideration}

The research was conducted with integrity and was not undertaken for personal gain. The research had no negative effect on the respondents. The researcher did not abuse the trust of the subjects by using the data collected to get somebody into trouble or to stigmatize them. Confidentiality and privacy was guaranteed and the consent of the respondents was sought before revealing any information.

\section{Results and Discussion}

The study intended to get response from all the Sugarcane outgrower companies in Kenya. There are nine sugar cane outgrower companies in Kenya and the researcher managed to collect data from all of them. This represents a response rate of 100 percent of the target population. The data was then coded and cleaned 
through extensive checks for consistency. The secondary data especially the published literature was used for validating the respondent's responses on the questionnaire. Data was analyzed using a set of descriptive and inferential statistics in statistical package for social sciences (SPSS). The independent variable of this study was internal control system and was characterized by control environment, risk assessment process, information system and control activities.

\section{Control Environment}

The respondents were asked to indicate the extent to which they disagree or agree with various aspects of control environmentin their respective sugarcane outgrower companies such as the management commitment to the operation of the system, management closely monitors implementation of internal control systems in our institution, management provides feedback to the junior officers about the operation of the system and appropriate measures are taken to correct misfeasance in operation of our accounting \& finance management system and their responses recorded in the Table 4.1.

Table 4.1 Aspects of control environment in sugarcane outgrower companies

\begin{tabular}{|c|c|c|c|}
\hline & Frequency & Percent & Cumulative Percent \\
\hline Strongly disagree & 5 & 27.8 & 27.8 \\
\hline Disagree & 2 & 11.1 & 38.9 \\
\hline Agree & 7 & 38.9 & 77.8 \\
\hline Strongly agree & 4 & 22.2 & 100.0 \\
\hline Total & 18 & 100.0 & \\
\hline
\end{tabular}

The study results in table 4.1 reveal that, 27.8 percent of the respondents strongly disagreed, 11.1 percent disagreed, 38.9 percent agreed and 22.2 percent strongly agreed with the various aspects of control environment.

\section{Risk Assessment Process}

The respondents were asked to indicate the extent to which they disagree or agree with various aspects of risk assessment process in their respective sugarcane outgrower companies. The five-point Likert scale with Strongly Disagree (1), Disagree (2), Fairly Agree (3), Agree (4) and Strongly Agree (5) was used and their responses recorded in Table 4.2.

Table 4.2 Risk assessment process in sugarcane outgrower companies

\begin{tabular}{lccc}
\hline & Frequency & Percent & Cumulative Percent \\
\hline Strongly disagree & 1 & 5.6 & 5.6 \\
Disagree & 7 & 38.9 & 44.4 \\
Agree & 6 & 33.3 & 77.8 \\
Strongly agree & 4 & 22.2 & 100.0 \\
Total & 18 & 100.0 & \\
\hline
\end{tabular}

From the study results on Table 4.2, majority of the study respondents generally agreed with most aspects of styles of executionin their respective Saccos. 22.2 percent of the respondents strongly agreed, 33.3 percent agreed, 38.9 percent disagreed while only 5.6 percent strongly disagreed.

\section{Information Systems}

The respondents were asked to indicate the extent to which they disagree or agree with various aspects of information systems in their respective sugarcane outgrower companies such as, the institution has an accounting and financial management system in place, there are enough measures to ensure the safety of the information system and internal auditor's appropriate recommendations are implemented and the results are presented in the Table 4.3.

Table 4.3The aspect of information system in the sugarcane outgrower companies

\begin{tabular}{lccc}
\hline & Frequency & Percent & Cumulative Percent \\
\hline Strongly disagree & 5 & 27.8 & 27.8 \\
Disagree & 2 & 11.1 & 38.9 \\
Agree & 7 & 38.9 & 77.8 \\
Strongly agree & 4 & 22.2 & 100.0 \\
Total & 18 & 100.0 & \\
\hline
\end{tabular}

The study findings revealed that over 22.2 percent of the study respondents strongly agreed with various aspects of information system, 38.9 percent agreed, 11.1 percent disagreed while 27.8 percent strongly disagreed with the various aspects of information systems in their sugarcane outgrower companies. 


\section{Control Activities}

The respondents were asked to indicate the extent to which they disagree or agree with various aspects of control activities such as, our institution has clear separation of roles, every employee's work checks on the others and there is appropriate supervision by senior staff on the work of their juniors in their respective sugarcane outgrower companies and their responses presented in the Table 4.4.

Table 4.4 Aspects of control activities

\begin{tabular}{lccc}
\hline & Frequency & Percent & Cumulative Percent \\
\hline Strongly disagree & 1 & 5.6 & 5.6 \\
Disagree & 7 & 38.9 & 44.4 \\
Agree & 6 & 33.3 & 77.8 \\
Strongly agree & 4 & 22.2 & 100.0 \\
Total & 18 & 100.0 & \\
\hline
\end{tabular}

\section{Financial Performance}

Financial performance on the other hand was the dependent variable of this study and was characterized bycost per unit, goal attainment and profitability or surplus for the non-profit making companies.

\section{Cost Per Unit}

The respondents were asked to indicate the extent to which they disagree or agree with various aspects of cost per unit in their respective sugarcane outgrower companies. The five-point Likert scale with Strongly Disagree (1), Disagree (2), Fairly Agree (3), Agree (4) and Strongly Agree (5) was used and their responses recorded in Table 4.5.

Table 4.5 Level of cost per unit

\begin{tabular}{llll}
\hline & Frequency & Percent & Cumulative Percent \\
\hline Strongly agree & 2 & 8.3 & 8.3 \\
Agree & 9 & 50.0 & 58.3 \\
Not sure & 3 & 16.7 & 75.0 \\
Disagree & 4 & 25.0 & 100.0 \\
Total & 18 & 100.0 & \\
\hline
\end{tabular}

From the study results, 8.3 percent strongly agreed, 50 percent agreed, 16.7.percent was not sure while 25 percent disagreed with the various aspects of cost per unit.

\section{Goal Attainment}

The respondents were asked to indicate the extent to which they disagree or agree with various aspects of goal attainment in their respective sugarcane outgrower companies such as, our institution has enough cash to meet its obligations effectively (as and when they fall due), our Institution has a well-developed Chart of Account and all company fees are dully corrected and the results are tabulated in the table 4.6.

\section{Table 4.6 the level of goal attainment}

\begin{tabular}{lccc}
\hline & Frequency & Percent & Cumulative percent \\
\hline Strongly disagree & 5 & 27.8 & 27.8 \\
Disagree & 2 & 11.1 & 38.9 \\
Agree & 7 & 38.9 & 77.8 \\
Strongly agree & 4 & 22.2 & 100.0 \\
Total & 18 & 100.0 & \\
\hline
\end{tabular}

The study findings revealed that over 22.2 percent of the study respondents strongly agreed with various aspects of information system, 38.9 percent agreed, 11.1 percent disagreed while 27.8 percent strongly disagreed with the various aspects of information systems in their sugarcane outgrower companies.

\section{Profitability}

The respondents were asked to indicate the extent to which they disagree or agree with various aspects of profitability in the respective sugarcane outgrower companies and the results presented in Table 4.7.

Table 4.7 Level of profitability

\begin{tabular}{lccc}
\hline & Frequency & Percent & Cumulative Percent \\
\hline Strongly disagree & 1 & 5.6 & 5.6 \\
Disagree & 7 & 38.9 & 44.4 \\
\hline \multicolumn{4}{c}{ www.iosrjournals.org }
\end{tabular}


Effects of Internal Control Systems on Financial Performance of Sugarcane out grower companies....

\begin{tabular}{lccc}
\hline Agree & 6 & 33.3 & 77.8 \\
Strongly agree & 4 & 22.2 & 100.0 \\
Total & 18 & 100.0 & \\
\hline
\end{tabular}

Study findings (table 4.7) show that 5.6 percent of the respondents strongly disagreed with the aspects of profitability, 38.9 percent disagree, 33.3 percent agreed while 22.2 percent strongly agreed with the aspects of profitability in their respective sugarcane outgrower companies.

\section{Hypothesis test on the effect of internal Control System on Performance.}

The study was based on the premise that internal control system influence financial performance of sugarcane outgrower companies.In order to assess the influence of internal control system on financial performance, the study had set the following null hypothesis; $\mathrm{H}_{01}$ : Internal control system does not have significant effect on financial performance of sugarcane outgrower companies.

In order to test the above hypothesis, the researcher used regression coefficient (beta $\beta$ ) with the test criteria set that the study should reject the null hypothesis $\mathrm{H}_{01}$ if $\beta \neq 0$ and $\mathrm{p}$-value $<\alpha$, otherwise fail to reject $\mathrm{H}_{0}$ and $\mathrm{F}$ tests were conducted to determine the indication and overall significance of the relationships respectively. All the questions in the questionnaire answered by the respondents had scores and scored marks depending on the response of the respondents. The marks were then added up and finally divided by number of respondents answering the questionnaire to enable the researcher attain the mean score of every question measuring the independent and dependent variables. In order to test the hypothesis, the aggregate mean score of financial Performance measures were regressed against the mean score of measures of internal control system and results presented in table 4.8 , and 4.9 .

Table 4.8 Goodness of fit analysis of internal control system on performance

\begin{tabular}{|l|l|l|l|l|}
\hline Sample size & R & R Square & Adjusted R Square & Std. Error of the Estimate \\
\hline 18 & 0.682 & 0.428 & 0.687 & 0.218 \\
\hline
\end{tabular}

From the study results, the regression results reveal that internal control system had overall positive significance impact on financial performance $(\mathrm{p}$-value $=0.016)$ Table 4.9. The regression results also shows that at individual level, there was a statistically significant positive linear relationship between internal control system and performance $(\beta=0.682)$ Table 4.8 in that the $p$-value is less than $0.05(0.004<0.05)$ Table 4.10 . The hypothesis criteria was that the null hypothesis $\mathrm{H}_{0}$ should be rejected if $\beta \neq 0$ and $p$-value $<\alpha$ otherwise fail to reject $\mathrm{H}_{0}$. From the above regression results $\beta=0.682 \neq 0$ and $0.016<0.05$, the study therefore rejects the null hypothesis and conclude that internal control system had significant effect on financial performance of sugarcane outgrower companies.

Table 4.9: Regression results for internal control system and performance

\begin{tabular}{rrrrrr}
\multicolumn{7}{c}{ Table 4.9.1 Overall significance: ANOVA (F-test) of Internal control system on performance } \\
& Sum of & Degree of & & F & $\begin{array}{r}\text { Significance } \\
\text { (p-value) }\end{array}$ \\
\hline Squares & Freedom & Mean Square & 3.218 & 49.018 & 0.016 \\
Regression & 2.018 & 4 & 0.124 & & \\
Residual & 1.640 & 11 & & & \\
Total & 3.368 & 15 & &
\end{tabular}

Table 4.9.2 Individual significance (T-test) of Internal control system on performance

\begin{tabular}{|c|c|c|c|c|c|}
\hline & \multicolumn{2}{|c|}{ Unstandardized Coefficients } & \multirow{2}{*}{$\begin{array}{r}\text { Standardized } \\
\text { Coefficients } \\
\text { Beta }(\beta)\end{array}$} & & \multirow{2}{*}{$\begin{array}{r}\text { Significance(p- } \\
\text { value) }\end{array}$} \\
\hline & $\mathrm{B}$ & Std. Error & & $\mathrm{T}$ & \\
\hline (Constant) & 1.446 & 2.482 & & 1.402 & 0.038 \\
\hline $\begin{array}{l}\text { Means of internal } \\
\text { control system }\end{array}$ & 0.451 & 0.402 & 0.682 & 1.068 & 0.004 \\
\hline
\end{tabular}

The regression results also shows that 42.8 percent of the performance of Saccos can be explained by Strategic leadership (Rsquared $=0.428$ ) and the relationship followed a simple regression model of the nature;

$\mathrm{FP}=1.446+0.682 \mathrm{ICS}$

Where:

ICS is the Internal Control System.

1.446 is a constant intercept term $(\alpha=1.446)$.

0.682 is the beta $(\beta=0.682)$ or the slope coefficient.

$\mathrm{FP}$ is the financial performance.

VIII. Summary, Conclusion And Recommendations 
Internal control system was characterized by control environment, risk assessment process, information system and control activities while financial performance was characterized by cost per unit, goal attainment and profitability or surplus. The regression results also shows that 42.8 percent of performance of Sugarcane outgrower companies can be explained by internal control system (Rsquared $=0.428$ ). This means that internal control system helps increase performance of Sugarcane outgrower companies by 42.8 percent.

\section{Recommendations}

Based on the findings and conclusions of the study, the following recommendations were made; Internal control system has been found to have a statistically positive effect on performance of Sugarcane outgrower companies hence there is need for the Sugar outgrower companies to improve on their internal control system

\section{Suggestions For Further Research}

Despite the fact that the study produced meaningful results it was subject to some limitations which provide avenues for further research. We have organizational factors such as technology, management structure, and age of the firm can bring more insights into the study hence need for further study which includes these other factors.

\section{References}

[1]. Ajowi E. (2005) Text Book for Auditing.Law Africa Publishing Company, Nairobi.

[2]. Asoke K. (2005) Financial Management, a Management Perspective. Prentice Hall, New Delhi.

[3]. Chandra P. (2002) Investment Analysis and Portfolio Management, Tata McGraw Company,

[4]. Chukwu P. (2012)The impact of internal control system on the financial Management of an organization (a case study of the nigeria bottling company plc, enugu)faculty of management and social sciences caritas university amorji-nike, Enugu.

[5]. COSO (2005).Internal Control; Integrated Framework, Tradeway.

[6]. Government of Kenya, Companies Act (Cap 486 of Laws of Kenya). Nairobi.

[7]. Hooks K. L, Kaplan S. E, Schultz J. J. (1994). Auditing, A journal of practice and Theory.

[8]. ICPAK Audit Quality Review Procedures

[9]. ISA UK and Ireland 315

[10]. KasnebNewsline (2011) TheProffessional Journal of Kasneb. Nairobi

[11]. KSA. (1999), Kenya Sugarcane Authority Yearbook of statistics. Nairobi.

[12]. KSB. (2003), Kenya Sugarcane Board Yearbook of statistics Nairobi.

[13]. KSB. (2004). Sugar Industry Strategic Plan 2004-2009, Nairobi.

[14]. KSB. (2004). Kenya Sugar Authority yearbook of statistics. Nairobi.

[15]. KSB. (2012). Sugar Board Strategic Plan 2004-2007,Nairobi.

[16]. Kothari C. R., (2010) Research Methodology: Methods and Techniques, $2^{\text {nd }}$ revised ed, New age international (P) Ltd. Publishers, New Delhi.

[17]. Manasseh (2004).A Text Book of Principles of Auditing.Mc more Accounting Books

[18]. Mawanda J. R (2008) The Relationship between Internal Control Systems and FinancialPerfomance in Institutions of Higher Learning. Kampala.

[19]. MOCO (2004) Financial Repo

[20]. Millichamp A. (2002).Auditing. Thomson Learning, London.

[21]. Mugenda M. O and Mugenda A. G (2003) Research Methods; Quantitative and Qualitative Approaches. Act Press Nairobi.

[22]. Muraleetharan P. (2010) Internal control and its impact on financial performance of organisation university of Jaffnan

[23]. Mwindi D. (2005).Auditing Focus Publishers Limited, Nairobi.

[24]. O'Connon, T. (2011), Survey Research Design Mega links in criminal justice,

[25]. (http;//www.drtomoconnor.com/3760/3760lect04.htm)

[26]. Pandey I. M. (2002) Financial Management $8^{\text {th }}$ Ed. Vikas Publishing House PVT LTD

[27]. Pandey I. M. (2010) Financial Management $10^{\text {th }}$ Ed. Vikas Publishing House PVT LTD

[28]. Pearce II A. et al (2010) Strategic Management; formulation and implementation, McGraw-Hill, NewYork

[29]. Pearce, J. \& Robinson, R. (2010)Strategic Management; Formulation Implementation and Control, McGraw-Hill Irwin U.S.A.

[30]. Porter, M. (1993) Differentiation St2rategy, Harvard Business Review, Vol. 74, Number, London

[31]. Saleemi N. A. (1997) Auditing Simplified. Saleemi Publishers, Nairobi

[32]. Sekaran, U. (2003), Research Methods for Business; A Skill building approach, 4 th Ed., John Wiley and Sons Inc., Singapore

[33]. Shah A. (2003) Local Public Financial Managemen

[34]. William K. et al (1999) Using Information Technology. McGnaw - Hill, Londonwww. mapsofthe world.com

[35]. The Institute of Internal Auditors. USA 